\title{
ガラス繊維-セメントペースト界面領域の組織と ガラス繊維補強モルタルの才丁学的特性
}

\section{FORMATION OF GLASS FIBER-CEMENT PASTE INTERFACIAL ZONE AND ITS EFFECT ON THE MECHANICAL PROPERTIES OF GLASS FIBER REINFORCED MORTAR}

\author{
五十嵐心一*・川 村 満 紀** \\ By Shin-ichi IGARASHI and Mitsunori KAWAMURA
}

\begin{abstract}
Microhardness measurements and EDXA analyses were made in the regions around glass fiber strands embedded in the cement paste to elucidate the effects of curing temperature and mineral admixtures on the microstructure of the interfacial zone between a glass fiber strand and cement paste matrix. The characteristics of flexural strength and toughness of glass fiber reinforced mortars were also discussed relating them to the results obtained by the microhardness measurements and EDXA analyses. Curing temperature significantly influenced the microhardness distribution patterns in the interfacial zone. Both the softest and the hardest region exist within the interfacial zone. The discontinuity in microhardness in the regions in samples cured at a high temperature $\left(38^{\circ} \mathrm{C}\right)$ appears to greatly affect the toughness of the corresponding glass fiber reinforced mortars. Overall microhardness distribution patterns were not changed by the addition of the mineral admixtures.
\end{abstract}

Keywords : age-embrittlement, interfacial region, microhardness

\section{1. まえがき}

ガラス繊維補強モルタル (GRC) の引張強度, 曲げ 強度は通常のモルタルと比較して大きく, またその耐衝 撃性も優れている. GRC は成形性にも富んでいるので, 任意の形状の高強度軽量薄肉部材の作成が容易であり, 現在では, 主に建築構造物の化粧板等の非構造パネル部 材として広く用いられている. しかし，ガラス繊維は鋼 繊維では得ることのできない非磁性などの特性を有し, 建築分野におけるパネル部材としての利用だけでなく, 土木分野への適用の可能性も十分考えられる ${ }^{1)}$. Okada ら ${ }^{2)}$ は RC はりやプレストレストコンクリートはりの断 面を GRC と複合化することにより，たわみやひびわれ 幅の低減が可能となることを示しており，また諸外国で は, GRC を橋梁の欄干や床版の永久型枠，および下水 管路のライニング材等に使用した実績がある゙3. わが国 では，GRCの土木分野への適用事例はかなり限られて いるが，二次製品のほかに土木構造物の補修，補強用吹

* 正会員 工修 金沢大学助手 工学部土木建設工学科 (7920 金沢市小立野 2-40-20)

** 正会員 工博 金沢大学教授 工学部土木建設工学科 (同上)
付けや舗装路盤等への適用が検討されている4) 7).

このように GRC の適用範囲が制限される主な原因 は, GRC は湿潤環境下や自然暴露下では, 材令の進行 に伴い強度や靶性が低下することである，特に，材令に 伴う靭性の低下は著しい. たとえば，ガラス繊維をコン クリートに混入してガラス繊維補強コンクリート（繊維 混入率 $1 \%$ ）とし, 屋外暴露を行った場合, 材令 3 年に おいて曲げ強度, 曲げ靶性係数および衝撃吸収エネル ギーは，それぞれ材令 28 日の值に対して約 $70 \%$, 約 $50 \%$ および約 $75 \%$ にまで低下する ${ }^{8}$.

現在，この GRC の曲げ強度および鞀性が材令に伴っ て低下するメカニズムに関して 2つの考え方がある. 1 つは使用する耐アルカリ性ガラス繊維の耐アルカリ性は 完全ではなく, セメントマトリックス中のアルカリ度の 高い細孔溶液によりガラス繊維は侵食されるために, GRC の曲げ強度や䩚性が低下するという考え方であ る $^{9)}$.もう 1 つはセメントの水和反応生成物, 特に $\mathrm{Ca}$ $(\mathrm{OH})_{2}$ がガラス繊維ストランド近傍やストランド内の フィラメント間を緻密に充填し, その結果, ガラス繊維 一セメンマトリックス間の付着力が増大し, ガラス瀻 維は引き抜けることなく破断するようになり，GRC は 脆性化するという考え方である(10),11). 前者に対しては, 
ガラス瀻維自身の耐アルカリ性を向上させることを目的 として，ガラス繊維の組成の改良や表面処理法の改善が 検討され，後者に対しては，主に繊維一マトリックス界 面の微視的構造を変化させるために, ポリマーの混入や 混合セメントの使用が検討されている.

現在，上述のいずれのメカニズムが，時間に伴う GRC の曲げ強度や䩚性の低下においてょり大きく作用 するかについてはまだ不明である。しかし，GRC 中か ら取り出したガラス瀻維は初期の引張強度を保持してい たこと，および，脆性化を生じた GRC 破断面の走査型 電子顕微鏡による詳細な観察では，ガラス瀻維表面には 侵食の跡が認められなかったこと，さらに，靶性が低下 した GRC 中のガラス繊維近傍には，比較的多量の $\mathrm{Ca}$ $(\mathrm{OH})_{2}$ の結晶が存在していたことより, 数年以内に生 ずる勒性や強度の低下は，一般にガラス繊維近傍におい て $\mathrm{Ca}(\mathrm{OH})_{2}$ の析出が活発であるためと考えられてい る ${ }^{12)}$ 。このような考えに基づいて GRC の耐久性改善の 一方策として，フライアッシュや高炉スラグの混入に よって，ガラス繊維一セメントマトリックス界面への $\mathrm{Ca}(\mathrm{OH})_{2}$ の析出を低減させようとする試みがなされて きたが，その結果は成功していないようである ${ }^{13), 14)}$. し かし，フライアッシュの混入による GRC の耐久性の改 善については，ポゾラン反応性や化学成分が同様であっ ても，使用するフライアッシュによって大きく異なると いう興味深い結果も得られている ${ }^{15)}$.一方, シリカフュー ムの GRC の耐久性改善効果に関しては, Bentur and Diamond $^{16)}$ は，あらかじめシリカフュームスラリーに 浸漬したガラス繊維ロービングを用いることによって, GRC の耐久性は大きく改善されたと報告している.

一般に, 脆性マトリックス瀻維補強複合材料の力学的 特性はマトリックス相とインクルージョン間の界面領域 の微視的構造に鋭敏である. 一方, セメント系複合材料 においては，骨材や繊維などのインクルージョンとセメ ントマトリックス相間の界面領域の微視的構造が本来の セメントペーストとはかなり大きく異なることが指摘さ れてきた ${ }^{17)}$. Bentur ら ${ }^{18)}$ はセメントペースト中を進行 するひびわれは，鋼瀻維-セメントペースト界面から数 $10 \mu \mathrm{m}$ 離れたところに存在する多孔性の領域において進 行方向を変え，このことが複合材料中のひびわれ伝播に 大きな影響を及ぼす可能性を指摘している.このように， 界面領域に存在する多孔性の領域の形成は，マトリック スの水セメント比と密接な関係を有し, 繊維の付着強度 にも重大な影響を及ぼすようである ${ }^{19)}$. GRC 中のガラ ス繊維周辺の界面領域に関しては，GRC 破断面の走查 型電子顕微鏡観察により, 界面およびストランド内部の 構造が明らかにされている(10). しかし，GRCの力学的 挙動に重大な影響を及ばすと考えられる界面から数 100 $\mu \mathrm{m}$ までの界面領域全体の微視的構造の形成過程に関し ては不明な点も多く, さらに, 界面領域全体の微視的構 造と GRC の力学的性質の関係について検討した研究は きわめて少ない.

本研究は, 微小硬度測定および EDXA 点分析により ガラス繊維ーセメントペースト界面領域全体の微視的構 造の形成過程を明らかにするとともに，これら微視的構 造の特徵とガラス繊維補強モルタルの力学的性質との関 連性を検討したものである.

\section{2. 実験方法}

\section{（1）使用材料}

使用したセメントは普通ポルトランドセメントであ る.細骨材としては, 川砂 (比重：2.64, 吸水率：0.95\%) を使用した．使用したガラス繊維は繊維長 $13 \mathrm{~mm}$ の市 販の耐アルカリ性ガラス繊維チョップドストランドであ り, 1 本のストランドは, 直径 $20 \mu \mathrm{m}$ のガラス繊維フィ ラメント 160 本より成る。繊維混入率（容積率）は０\% から $2.5 \%$ まで変化させた. 使用したフライアッシュお よびシリカフュームの物理的性質を Table 1 に示す。 シ リカフュームおよびフライアッシュ混入モルタルにおけ るそ机ぞれの混和材の置換率は $10 \%$ および $20 \%$ であ る.シリカフューム混入モルタルにおいては，セメント 重量の $0.8 \%$ の高性能減水剂を添加した．ガラス繊維補 強モルタルの配合は Table 2 のとおりである.

\section{（2）ガラス繊維補強モルタルの曲げ強度試験}

ガラス繊維補強モルタル供試体 $(40 \times 40 \times 160 \mathrm{~mm})$ はプレミックス法により作成した。すなわち，まず JIS R 5201 に従ってモルタルを練りまぜ後，30 秒間分散さ せたガラス繊維を投入しながら練りまぜた。その後，さ らに 30 秒間練りまぜた。モルタル供試体は，恒温恒湿 室 $\left(20^{\circ} \mathrm{C}, 90 \%\right.$ R. H. $)$ に 24 時間静置後脱型し，次の 3 条件の下で養生した。

a) $5^{\circ} \mathrm{C}$ における水中養生

b） $20^{\circ} \mathrm{C}$ における水中養生

c) $38^{\circ} \mathrm{C}$ に保持された湿気箱中における促進養生

所定材令において精密万能試験機を用いて曲げ強度試 験を行った．載荷方式は中央 1 点集中載荷である．得ら

Table 1 Physical properties of admixture.

\begin{tabular}{lcc}
\hline & Specific Gravity & Surface Area $\left(\mathrm{m}^{2} / \mathrm{g}\right)$ \\
\hline Flyash & 2.23 & 2.1 \\
Silica Fume & 2.33 & 24.2 \\
\hline
\end{tabular}

Table 2 Mix proportions of glass fiber reinforced mortars.

\begin{tabular}{lcc:c}
\hline & W/C & C $:$ S $:$ Flyash or \\
& & & Silica Fume \\
\hline Admixture-free & 0.55 & $1: 2: 0$ \\
Flyash-bearing & 0.55 & $0.8: 2: 0.2$ \\
Silica Fume-bearing & 0.55 & $0.9: 2: 0.1$ \\
\hline
\end{tabular}


れた荷重-たわみ曲線下のたわみ $1 \mathrm{~mm}$ までの面積を夕 フネスとした.

\section{（3）微小硬度測定および EDXA 点分析}

GRC 中の界面領域において注目すべき界面領域の形 成はモルタル中のセメントペースト相の組織変化であ る.したがって Fig. 1 に示すように，モルタルのセメン トペースト相に相当する水セメント比が $55 \%$ のセメン トペースト中に 9 本のガラス繊維ストランドを埋め込 み，これをモルタル供試体と同様の 3 条件下において看 生した. 所定材令において，立方体供試体から埋め込み 繊維の方向と直角方向に薄板を切り出し，薄板の表面を ダイアモンドスラリーを用いて研磨した。その後，研磨 した面内に現われた 1 本のガラス繊維ストランドーセメ ントペースト界面領域の微小硬度（ビッカース硬度，荷 重：2g）を測定した. 微小硬度測定を終了した供試体 は真空中にて乾燥し，研磨面に金蒸着を行った後, EDXA 分析に供した。界面領域の EDXA 点分析の計測 時間は 100 秒であり， $\mathrm{Ca}, \mathrm{Si}$ の $\mathrm{K} \alpha$ 線の積分強度值を 求めた.また，鋼繊維 (直径 $0.5 \mathrm{~mm}$, カットファイバー) を用いて，同様に微小硬度测定を行った。

\section{（4）モデル溶液に浸漬されたガラス綫維ストランド の引張強度試験}

使用したガラス繊維の耐アルカリ性を確認するため に，本実験において使用したモルタル中の細孔溶液に相 当するモデル溶液中に浸漬されたガラス繊維の引張強度 を求めた．モルタルのセメントペースト相に相当する水 セメント比が $55 \%$ のセメントペースト円柱供試体（直 径 $4 \mathrm{~cm} \times 10 \mathrm{~cm})$ を作成し, 促進養生 $\left(38^{\circ} \mathrm{C}, 100 \%\right.$ R. H. ) を行った．材令 7 日において供試体から高圧装置 ${ }^{20)}$ を用 いて細孔溶液をしぼり出し， $\mathrm{OH}^{-}$イオン濃度は塩酸に 対する滴定，また， $\mathrm{Na}^{+}$および $\mathrm{K}^{+}$イオン濃度は原子吸 光分析により決定した. 細孔溶液の分析結果を Table 3 に示す. $\mathrm{NaOH}$ および $\mathrm{KOH}$ の 1 級試薬を用いて Table 3 に示されるものと同一の化学組成の溶液を作成し, こ れにガラス繊維を浸漬し，湿気箱中 $\left(38^{\circ} \mathrm{C} ， 100 \%\right) に$

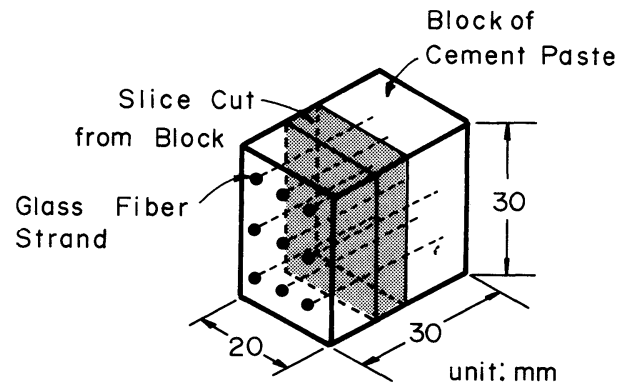

Fig. 1 Schematic diagram of a specimen for microhardness measurement and EDXA analysis.
貯蔵した. 所定期間保存後，溶液中から取り出したガラ ス繊維を蒸留水で十分洗浄した後，24 時間室温にて乾 燥したガラス繊維ストランドに対して引張強度試験（載 荷速度：0.5 mm/min) を行った。

（5）セメントペースト中より取り出したガラス綫維 の引張強度試験

モルタルのセメントペースト相に相当する水セメント 比が $55 \%$ の普通セメントペースト円柱供試体（直径 3 $\mathrm{cm} \times 5 \mathrm{~cm})$ の中央にガラス繊維ストランドを 1 本埋め 込んだ後，促進養生 $\left(38^{\circ} \mathrm{C}, 100 \%\right.$ R.H. ) を行った. 材令 14 日において供試体を圧裂により 2 分して，ガラ ス繊維ストランドを取り出した.このストランドから フィラメントを 1 本ずつ取り出し， JIS R 7601 に従つ てモノフィラメントの引張強度試験を行った。

\section{3. 実験 結果}

\section{（1）混和材無混入ガラス織維補強モルタル}

a）養生温度が曲げ強度およびタフネスに及ぼす影響

Fig. 2 において混和材無混入ガラス繊維補強モルタル の曲げ強度の材令に伴う変化を示す. $5^{\circ} \mathrm{C}$ における水中 養生の場合，曲げ強度は材令 180 日まで材令の進行に伴 い増大するが，材令 360 日において，纎維混入率 $2.0 \%$, $2.5 \%$ ののの曲げ強度は大きく低下する. $20^{\circ} \mathrm{C}$ にお ける水中養生の場合も，材令 360 日において曲げ強度は 若干低下している. 促進養生下では, 材令の進行に伴う 曲げ強度の変化はほとんどなく, また, 繊維混入率間の 曲げ強度の差も小さい。

Fig. 3 は各養生条件下におけるガラス繊維補強モル夕 ルのタフネスの材令に伴う変化を示したものである. $5^{\circ} \mathrm{C}$ における水中養生の場合は，タフネスは材令 180 日 までは増大するが，材令 360 日において低下している. $20^{\circ} \mathrm{C}$ における水中養生の場合は，材令 90 日以後夕フネ スは低下し，材令 360 日では繊維混入率間のタフネスの 差も小さくなっている．促進養生を行った場合は，脆性 化の進行は著しく，材令 28 日においてすでにタフネス は大きく低下し，材令 360 日では，ガラス繊維混入によ る䩲性の付与は完全に失われている.

b）養生温度がガラス繊維-セメントペースト界面領 域の組織に及ぼす影響

Fig. 4 は各材令における普通セメントペースト中に埋 め込まれたガラス繊維周辺の微小硬度分布を示したもの

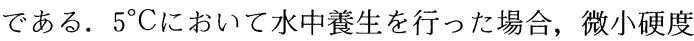

Table 3 Chemical composition of pore solution.

\begin{tabular}{lc}
\hline & Concentration $(\mathrm{mol} / 1)$ \\
\hline $\mathrm{Na}+$ & 0.119 \\
$\mathrm{~K}+$ & 0.229 \\
$\mathrm{OH}^{-}$ & 0.398 \\
\hline
\end{tabular}




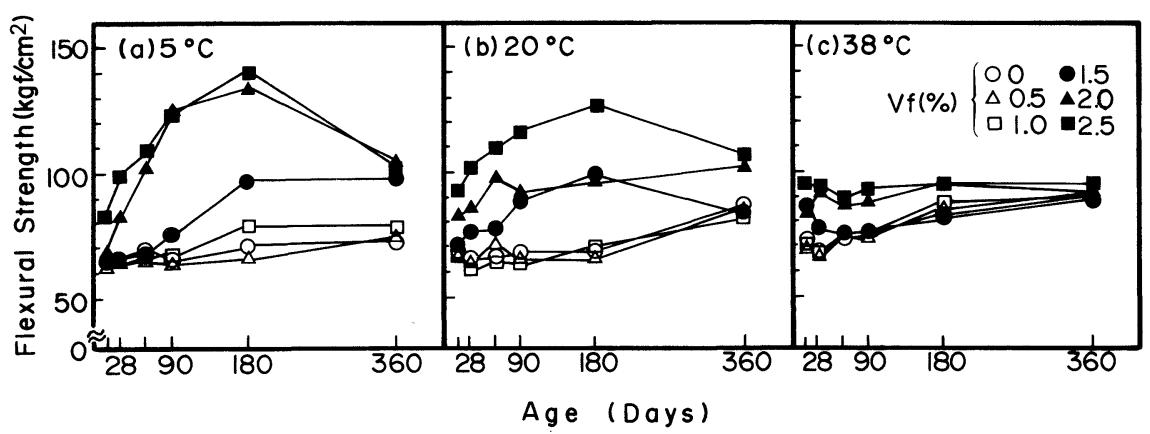

Fig. 2 Flexural strength of glass fiber reinforced mortars without admixture.

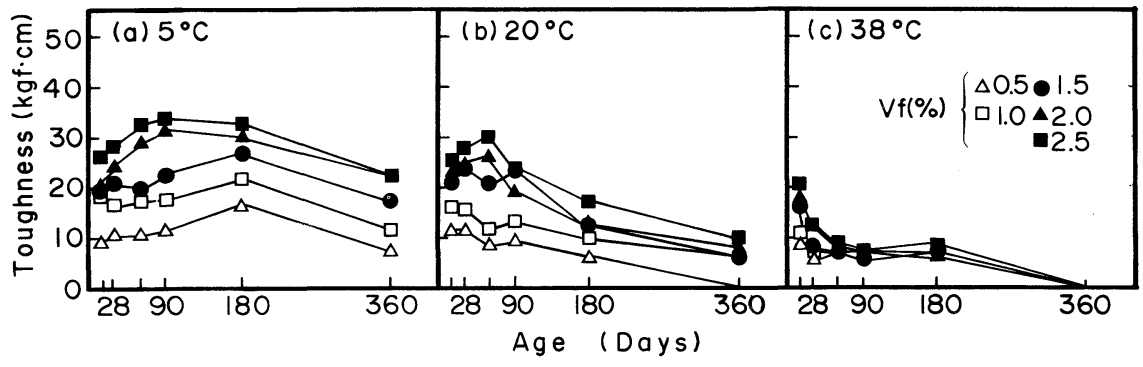

Fig. 3 Toughness of glass fiber reinforced mortars without admixture.

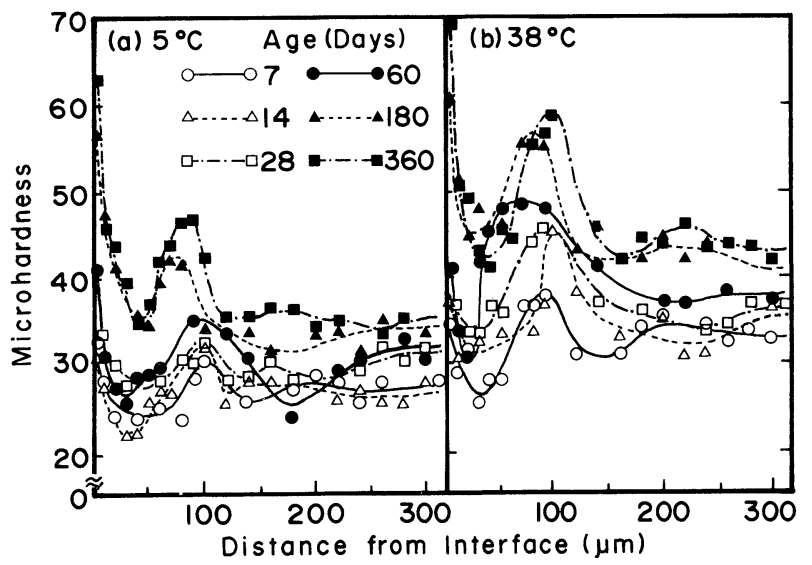

Fig. 4 Microhardness distribution patterns around a glass fiber strand in the admixture-free cement paste.

は界面からの距離約 $50 \mu \mathrm{m}$ 付近まで距離とともに低下 し，その後約 $100 \mu \mathrm{m}$ まで増大し，再び低下する．この ような微小硬度の分布の材令に伴う変化は, 材令 60 日 までは小さいようである.しかし，材令 180 日以後，ガ ラス繊維隣接部分の微小硬度は著しく増大し，また，界 面から約 $100 \mu \mathrm{m}$ 付近の微小硬度が, 界面の影響を受け ない領域のセメントペースト (bulk セメントペースト) よりもかなり大きくなっている，促進養生下では， $5^{\circ} \mathrm{C}$ における水中養生の場合に比べて, 初期材令よりガラス
繊維隣接部分の微小硬度は大きく，また，界面 から約 $100 \mu \mathrm{m}$ 付近にもピークが認められる. これらの結果より，促進養生を行った場合，界 面領域の組織は，初期材令においてすでにかな り不均質であり， $5^{\circ} \mathrm{C}$ における水中養生では， 180 日以後の長期材令において, 界面領域は不 均質になることがわかる。

c) 界面領域の $\mathrm{Ca} / \mathrm{Si}$ カウント比

Fig. 5 は界面からの距離 $100 \mu \mathrm{m}$ 以内の領域 における $\mathrm{Ca} / \mathrm{Si}$ カウント比の分布を示したも のである. $5^{\circ} \mathrm{C}$ における水中養生の場合，界面 からの距離に伴う $\mathrm{Ca} / \mathrm{Si}$ カウント比の変化は 明瞭ではない. 一方, 促進養生を行った場合は, この領域内での $\mathrm{Ca} / \mathrm{Si}$ カウント比の変動はか なり大きい。促進養生下において認められる

$\mathrm{Ca} / \mathrm{Si}$ カウント比のピークは, その位置で $\mathrm{Ca}$ に富む水和物が生成されていることを示すと考えられる が，微小硬度值と $\mathrm{Ca} / \mathrm{Si}$ カウント比の関係は明らかで はない。

（2）混和材混入ガラス瀻維補強モルタル

a）養生温度が曲げ強度およびタフネスに及ぼす影響

Fig. 6 および Fig. 7 はそれぞれフライアッシュおよび シリカフューム混入モルタルの曲げ強度の材令の進行に 伴う変化を示したものである.フライアッシュを混入し た場合， $5^{\circ} \mathrm{C}$ および $20^{\circ} \mathrm{C}$ における水中養生のいずれに 


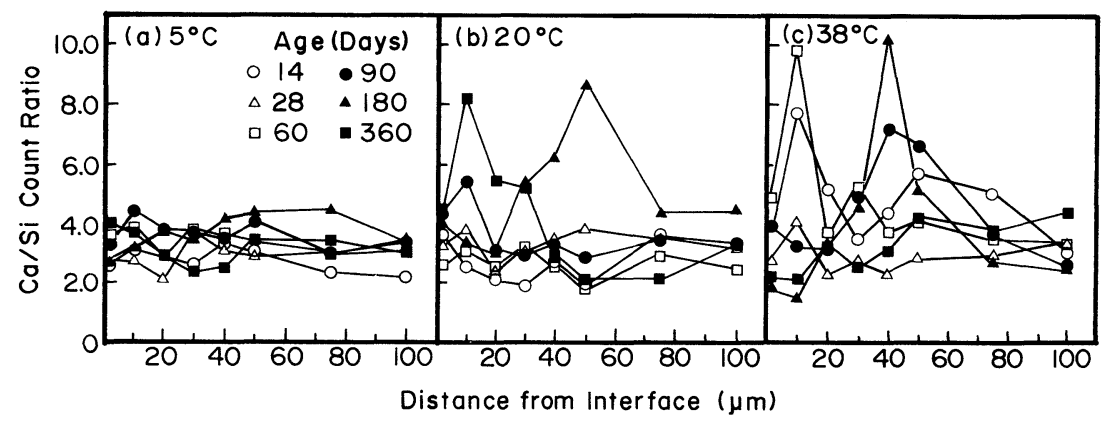

Fig. $5 \mathrm{Ca} / \mathrm{Si}$ count ratio in the interfacial region in the admixture-free cement paste.

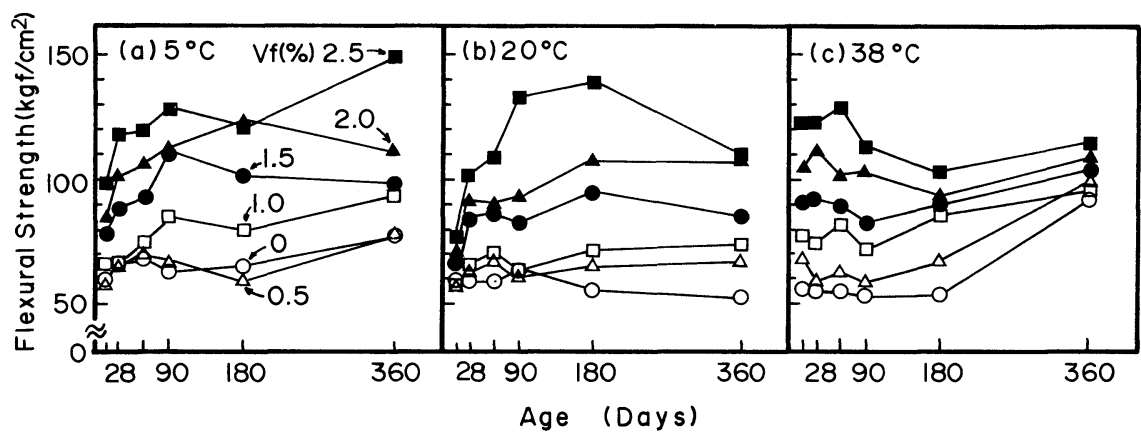

Fig. 6 Flexural strength of glass fiber reinforced mortars with flyash.

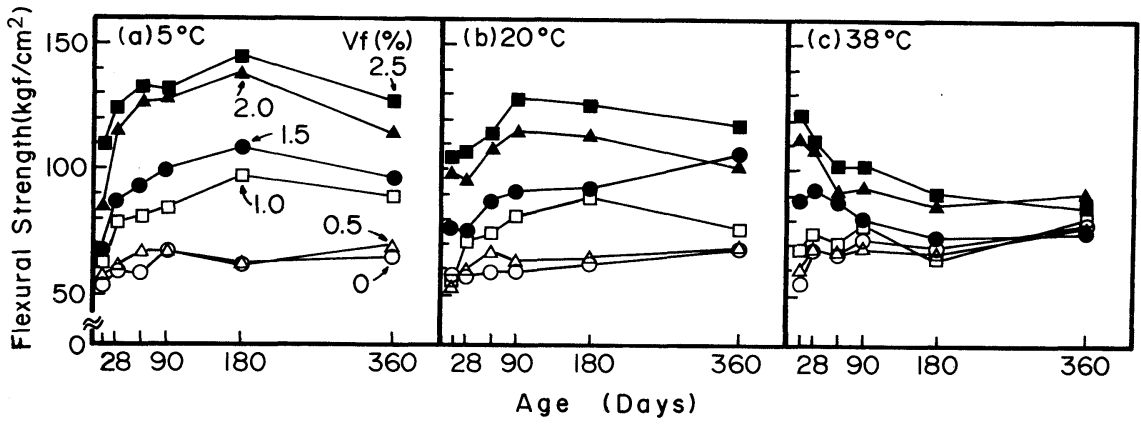

Fig. 7 Flexural strength of glass fiber reinforced mortars with silica fume.

おいても，繊維混入率 $2.5 \%$ のもを除いて，材令 90 日以後の曲げ強度の変化は小さいようである。一方, $38^{\circ} \mathrm{C}$ で促進養生を行った場合は, 低繊維混入率のもの に材令 360 日において曲げ強度の増大が認められるが, 繊維混入率 $1 \%$ 以上では，材令 180 日以後の曲げ強度の 変化は比較的小さい. しかし，360日における繊維混入 率間の曲げ強度の差が小さく, ガラス繊維補強モルタル の曲げ強度とマトリックス自体の曲げ強度 $\left(V_{f}=0 \%\right)$ との間に大きな差異は認められない. シリカフューム混 入の場合は, $5^{\circ} \mathrm{C}$ およ゙ $20^{\circ} \mathrm{C}$ のいずれの水中養生にお いても, フライアッシュ混入モルタルと同様の傾向を示 すが, 促進養生下では, 繊維混入率 $1.5 \%$ 以上のものに
おいて, 材令の進行に伴い曲げ強度に若干の低下が認め られ，材令 360 日では，繊維混入率間の差もかなり小さ くなっている.

Fig. 8 および Fig. 9 はフライアッシュおよびシリカ フューム混入モルタルのタフネスの材令に伴う変化状況 を示したものである. いずれのモルタルにおいても， $5^{\circ} \mathrm{C}$ における水中養生の場合，材令 180 日以後に夕フネ スの低下が生じ始める。しかし，90日または180日材

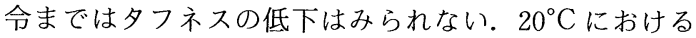
水中養生の場合は, いずれのモルタルにおいても低繊維 混入率では夕フネスの材令に伴う変化は小さいが, 繊維 混入率 $2.0 \%$ 以上のものは，材令 180 日以後における夕 


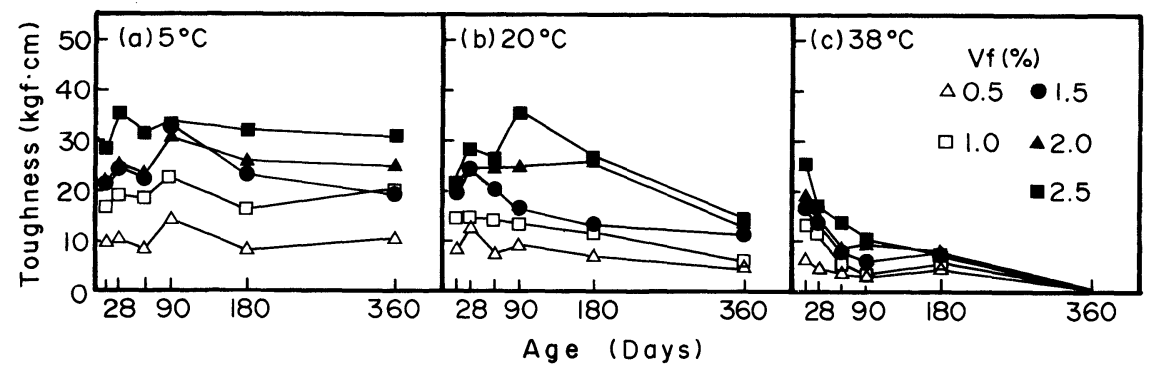

Fig. 8 Toughness of glass fiber reinforced mortars with flyash.

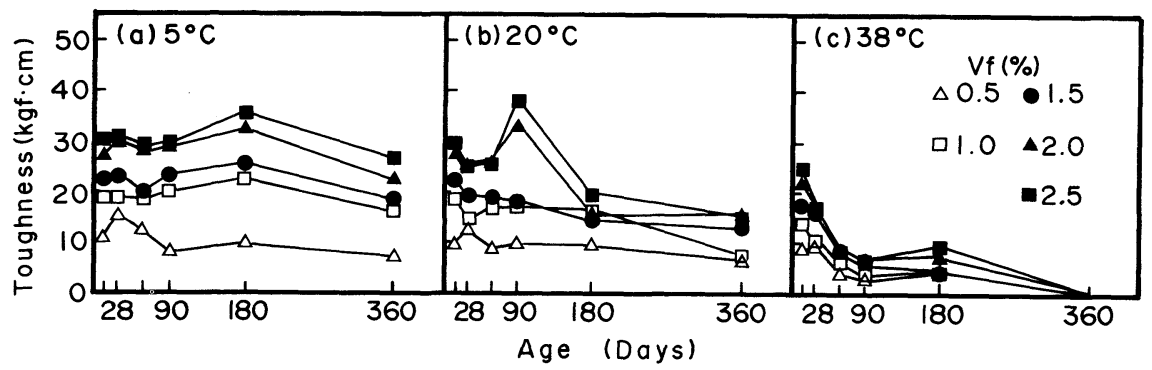

Fig. 9 Toughness of glass fiber reinforced mortars with silica fume.

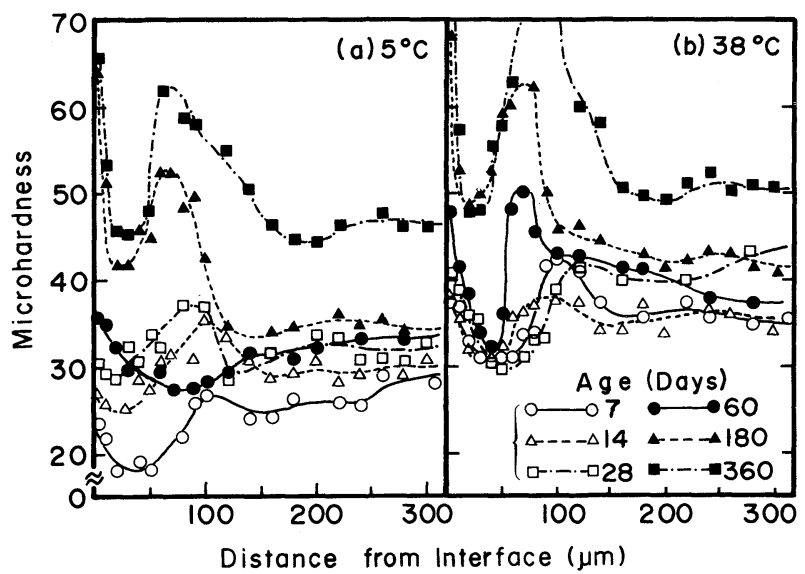

Fig. 10 Microhardness distribution patterns around a glass fiber strand in the flyash-bearing cement paste.

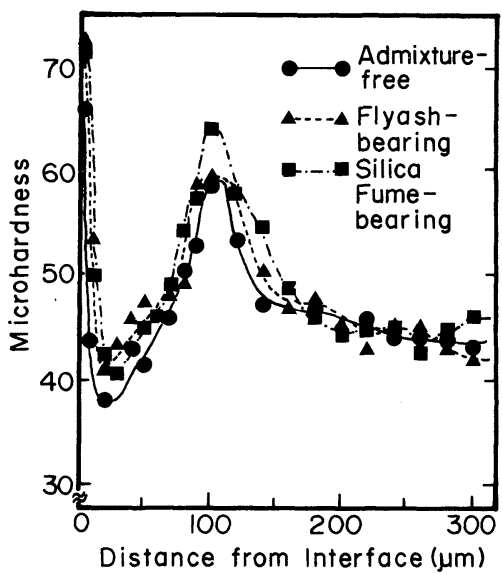

Fig. 11 Microhardness distribution patterns around a glass fiber strand in various cement paste.
フネスの低下は著しい. Fig. 8 (c) および Fig.9 (c) より，促進養生下では，フライアッシュおよびシリカ フューム混入モルタルのいずれにおいても，混和材無混 入モルタルの場合と同様に，材令に伴う脆性化の進行は 著しく，材令 360 日において，ガラス繊維混入による補 強効果は完全に失われていることがわかる. Fig. 3,

Fig. 8 および Fig. 9 に示される結果を比較すると, フラ イアッシュの混入により，ガラス緘維補強モルタルの脆 性化の進行は多少緩和されることがわかる. b）養生温度がガラス繊維-混和材混入セメントペー ス卜界面領域の微小硬度分布に及ぼす影響

Fig. 10 は， $5^{\circ} \mathrm{C}$ における水中養生および促進養生を 行ったフライアッシュ混入セメントペースト中のガラス 繊維-セメントペースト界面領域の微小硬度分布を示し たものである. Fig.10よりいずれの養生においても比 較的早期材令においては界面から数 $10 \mu \mathrm{m}$ 離れた位置 の微小硬度は最も低くなり, その位置加ら約 $100 \mu \mathrm{m}$ 付 近まで再び増大するという傾向は混和材無添加モルタル の場合（Fig.4）と同様である. しかし， $5^{\circ} \mathrm{C}$ における 


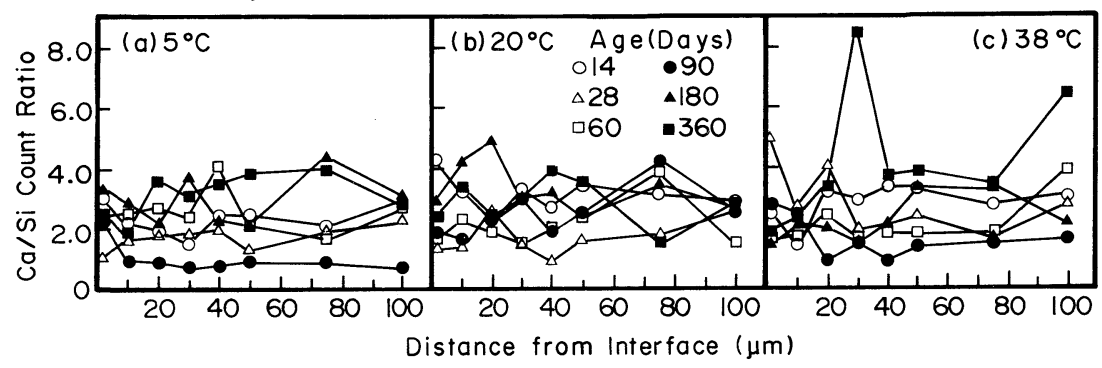

Fig. $12 \mathrm{Ca} / \mathrm{Si}$ count ratio in the interfacial region in the flyash-bearing cement paste.

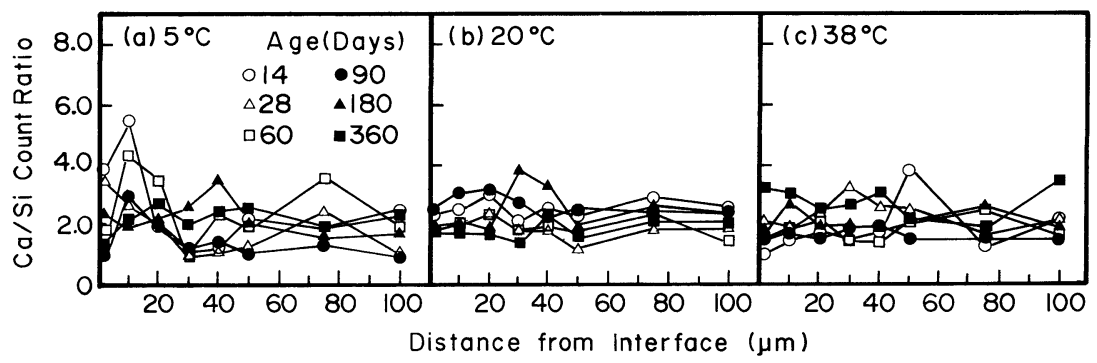

Fig. $13 \mathrm{Ca} / \mathrm{Si}$ count ratio in the interfacial region in the silica fume-bearing cement paste.

水中養生の場合は，微小硬度の界面からの距離に伴う変 化は材令 60 日までは緩やかであり，ガラス繊維隣接部 分の微小硬度も他の領域に比べてそれほど大きくない。 しかし，材令 180 日以後，ガラス繊維隣接部分の微小硬 度は著しく増大し，また界面からの距離約 $100 \mu \mathrm{m}$ 付近 の微小硬度も増大する。一方, 促進養生下では, 初期材 令上り界面隣接部分の微小硬度は界面からの距離数 10 $\mu \mathrm{m}$ の領域よりもかなり大きな值を示し，また界面から 約 $100 \mu \mathrm{m}$ の領域の微小硬度の増大も著しい.

Fig. 11 は， $20^{\circ} \mathrm{C}$ において水中養生を行った普通セメ ントペースト，フライアッシュ混入およびシリカフュー ム混入セメントペーストに対する材令 360 日における界 面領域の微小硬度分布を示したものである．Fig. 11 よ り，3つの異なったセメントペーストマトリックス中に 埋め込まれたガラス繊維ストランドの周辺における微小 硬度分布の形は互いにきわめて類似していることがわか る.この結果より, 界面領域内の不均質性を示す微小硬 度の不連続な変化は，フライアッシュおよびシリカ フュームの混入によって影響を受けることはないといえ る.

c) 界面領域の $\mathrm{Ca} / \mathrm{Si}$ カウント比

Fig. 12 および Fig. 13 はそれぞれフライアッシュおよ びシリカフュームを混入したセメントペーストーガラス 繊維ストランドの界面領域の $\mathrm{Ca} / \mathrm{Si}$ カウント比の分布 を示す. Fig. 12 および Fig. 13 と Fig. 5 の結果を比較す ると，混和材を混入したペーストにおいては普通セメン トペーストに比べて全体として界面領域の $\mathrm{Ca} / \mathrm{Si}$ カウ
ント比は低く，また，Caに富んだ点の数も少ない，

\section{4. 考察}

3.において示したように，混和材混入の有無にかか わらずガラス繊維補強モルタルの勒性は促進養生を行っ た場合はかなり早期より急速に低下し始めるが， $5^{\circ} \mathrm{C}$ に おける水中で養生した場合は，材令 360 日まで初期の夕 フネスはほぼ保持されることがわかる。一方，曲げ強度 に関しては，いずれのガラス繊維補強モルタルにおいて も促進養生を行った場合は，材令に伴うマトリックス自 身の曲げ強度との差が小さくなり，ガラス繊維による補 強効果の低下が認められる. しかし, 水中養生 $\left(5^{\circ} \mathrm{C}\right.$, $\left.20^{\circ} \mathrm{C}\right)$ を行った場合，曲げ強度は若干低下するが，材 令 360 日においても繊維混入率間の曲げ強度差が認めら れ，ガラス瀻維による補強効果は失われていない．以下 において，このようなガラス繊維補強モルタルの脆性化 の原因について，アルカリ度の高い溶液中におけるガラ ス繊維の劣化の可能性およびガラス瀻維-セメントペー ス卜界面領域の微視的構造の特徵という 2 つ観点から 論ずる.

\section{（1）モルタル中におけるガラス繊維の耐アルカリ性 の評価}

Table 4 に示すように，本実験におけるガラス瀻維補 強モルタルのセメントペースト相中の細孔溶液に対応す るモデル溶液中に（Table 3参照）14 日および28日間 浸漬したガラス瀻維の引張強度の低下は, 温度 $38^{\circ} \mathrm{C}$ に おいてもきわめて小さい. 
Table 5 はセメントペーストから取り出したフィラメ ント 32 本に対する伸び率, 引張強度および弾性係数の 平均值を示したものである.フィラメントの引張強度は セメントペーストへの埋め込み前のガラス繊維ストラン ドと同等の引張強度を保持しており, また，破断時の伸 び率も約 $2 \%$ であり，もとのガラス繊維の值を保持して (る ${ }^{21)}$. ガラス繊維の引張強度は欠陥の存在に敏感であ り, 引張強度試験用試料作成中のガラス繊維の損傷は避 けられないため, 引張強度のばらつきはかなり大きくな る.しかし，これらの結果より考えて，少なくとも本実 験にて認められた早期のガラス瀻維補強モルタルの靶性 低下 (Fig. 3(c) 参照) は，アルカリ度の高い環境下に おけるガラス繊維自身の劣化に起因するものではないよ うである。

（2）ガラス織維-セメントペースト界面領域の微視 的構造の特徴とガラス綫維補強モルタルの脆性 化

3.において述べたように，ガラス繊維-セメントペー ス卜界面領域では, 微小硬度は界面からの距離に伴い低 下し, 約 $50 \mu \mathrm{m}$ 付近の最も軟らかい領域に達した後再 び増大し約 $100 \mu \mathrm{m}$ 付近でピーク值に達し, その後再び 微小硬度は減少して一定值になる。このような微小硬度 の界面からの距離に伴う変化のパターンは, 混和材混入 の有無にかかわらず,いずれのガラス繊維-セメントペー ストの界面領域においても同様である.しかし，養生温 度が界面領域の微小硬度に及ぼす影響は顕著であり， $5^{\circ} \mathrm{C}$ における水中養生と促進養生の間には, 次の 2 つの 点で明確な相違が認められる。

第 1 の相違点としては, 促進養生においてはかなりの 早期の材令より，界面から約 $100 \mu \mathrm{m}$ における微小硬度 が bulk のセメントペースト相よりも大きな微小硬度值 を示し，材令に伴いこの領域の微小硬度は著しく増大す

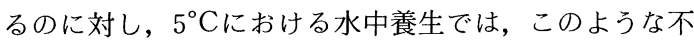
連続な微小硬度の増大はかなり長期の材令において現わ れるという点である. すなわち, 促進養生下においては, かなり初期の材令において, 界面より約 $20 \mu \mathrm{m}$ から約

Table 4 Tensile strength of glass fiber.

\begin{tabular}{lcc}
\hline Immersion & $\begin{array}{c}\text { Tensile } \\
\text { Period(Days) }\end{array}$ & $\begin{array}{l}\text { Standard } \\
\text { Deviation }\left(\mathrm{kgf} / \mathrm{mm}^{2}\right)\end{array}$ \\
\hline 0 & 94.55 & 13.71 \\
14 & 88.54 & 25.43 \\
28 & 89.64 & 30.65 \\
\hline
\end{tabular}

Table 5 Tensile strength of a glass fiber filament.

\begin{tabular}{|c|c|c|c|}
\hline & $\begin{array}{l}\text { Strain at } \\
\text { Failure } \\
(\%)\end{array}$ & $\begin{array}{c}\text { Tensile } \\
\text { Strength } \\
\left(\mathrm{kgf} / \mathrm{mm}^{2}\right)\end{array}$ & $\begin{array}{l}\text { Young's } \\
\text { Modulus } \\
\left(\mathrm{kgf} / \mathrm{mm}^{2}\right)\end{array}$ \\
\hline Mean Value & 1.83 & 99.80 & 55.1 \\
\hline $\begin{array}{l}\text { Standard } \\
\text { Deviation }\end{array}$ & 0.55 & 27.70 & 0.9 \\
\hline
\end{tabular}

$100 \mu \mathrm{m}$ の範囲において不連続に微小硬度值が変化する 不均質な構造が形成される。 セメントペーストの弾性係 数は微小硬度值に比例するので22), 界面より約 $100 \mu \mathrm{m}$ におけるピーク位置と約 $20 \mu \mathrm{m}$ における底部との間に おける弾性係数の差異はかなり大きい.このような不均 質な構造においては，ひびわれの発生および伝播がより 容易になるであろう.

第 2 の相違点は, 促進養生を行ったものの方が, 初期 材令よりガラス繊維隣接部分の微小硬度が初期材令より 大きく, 微小硬度值は底部域に向かって大きく低下する

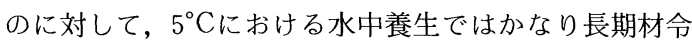
において界面隣接部分の微小硬度が急激に増大する。こ の界面隣接部分の微小硬度の増大は, この領域における 剛性の増大を示す.すなわち，このことはガラス繊維の 引き抜けに対する界面のせん断抵抗の増大を意味する. したがって,一端ひびわれがガラス繊維を貫通した後は, ひびわれ面を横切るガラス瀻維は，セメントペーストと の付着力の増大により引き抜けることなく破断しやすく なると考えられる.

以上の考察より, ガラス繊維補強モルタルの脆性化は, ガラス繊維隣接部分のセメントペーストの剛性の増大ま たは界面から 20～100 $\mu \mathrm{m}$ 間における不連続な剛性の変 化のいずれか，またはこの両者に起因するといえる，以 上のようなガラス繊維一セメントペースト界面領域にお ける長期にわたる特異な組織の変化は，ガラス繊維とセ メントペースト間に生ずる特有のもののようである．鋼 繊維一セメントペースト界面領域については, Pinchin $ら^{23)}$ が鋼繊維の引き抜け挙動との関連において, bulk セメントペーストにおいてはかなり長期にわたって硬化 や強度の増大が認められるが，界面領域の強度の增大は 早期に終了し, 1 週以後における界面構造の変化はほと

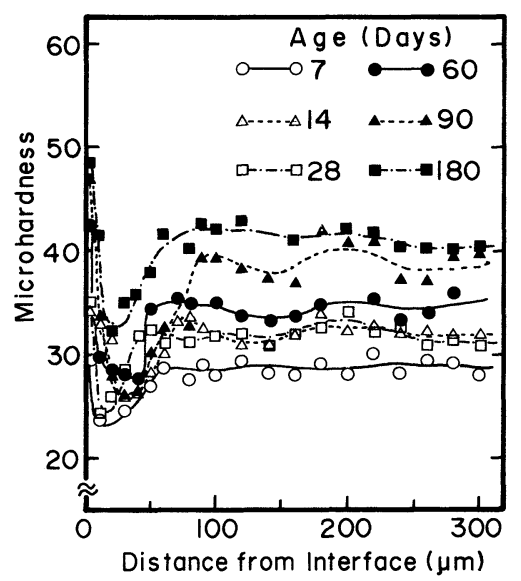

Fig. 14 Microhardness distribution patterns around a steel fiber in the admixture-free cement paste. 
んどみられないとしている.Fig. 14 は鋼繊維-セメント ペースト界面領域の微小硬度分布の材令に伴う変化を示 したものである．界面隣接部分において微小硬度の増大 は認められるが，界面領域全体の微小硬度の材令に伴う 変化はかなり小さい。この結果はPinchinらの結果と 一致する. Fig. 14 における微小硬度分布のパターンよ り，鋼繊維-セメントペースト界面では，界面から数 10 $\mu \mathrm{m}$ 離れた低硬度域における微小硬度の材令に伴う変化 はほとん亡゙なく，長期材令においても，擬脱付着 (pseudo-debonding) が生じていると考えられる.し かし，Fig.4，10 および 11 におけるガラス繊維-セメン トペーストの界面領域の微小硬度分布より，GRCにお いては，低硬度域の微小硬度は長期材令においても bulk セメントペーストと同程度以上に増大しており， ガラス繊維補強モルタルにおけるガラス繊維の脱付着 (付着破壊)-引き抜け過程は鋼繊維補強モルタルとは大 きく異なると考えられる。

ガラス繊維の場合，長期にわたって，界面領域の組織 の変化が認められ，付着強度も材令に伴い増大する ${ }^{24), 25)}$. 一般に，GRCにおいては未水和セメント粒子が長期材 令においても多く存在すること ${ }^{26)}$ ，および打設時にガラ ス繊維ストランドに多くの水を取り込むこと ${ }^{27)}$ が，界 面領域の不均質な組織形成亡関連している可能性があ る.しかし，界面からの距離約 $100 \mu \mathrm{m}$ 付近において微 小硬度の高い領域が形成されるメカニズムについては, さらに詳細な検討が必要であると思われる.

\section{5. 結 論}

ガラス纎維補強モルタルの材令に伴う脆性化を解明す るためにガラス繊維一セメントペースト界面領域の組織 に着目し，この組織の材令に伴う変化を養生温度および 混和材の混入の有無と関連づけながら検討した．本研究 により得られた結果をまとめると以下のとおりである.

（1） $5{ }^{\circ} \mathrm{C}$ およ゙ $20^{\circ} \mathrm{C}$ において水中養生を行ったガ ラス瀻維補強モルタルの曲げ強度は，材令 180 日まで 徐々に増大するが，材令 360 日においては，繊維混入率 の大きいものに曲げ強度の若干の低下が認められる．促 進養生を行ったガラス繊維補強モルタルでは，材令の進 行に伴い繊維混入率間の曲げ強度の差が小さくなる．ま た，このような曲げ強度の材令に伴う変化の傾向は, 混 和材の混入の有無にかかわらず同様である。

（2）ガラス繊維補強モルタルのタフネスは養生温度 の高いものほど早期に低下し，促進養生下では，材令 360 日においてガラス繊維の鞀性補強効果は完全に失わ れる.低温において養生したガラス繊維補強モルタルは, 長期材令においてタフネスはある程度低下するが，初期 材令においてはタフネスは保持される.
（3）混和材の混入によってガラス繊維補強モルタル のタフネスの低下は抑制できないが，その進行は多少遅 延されるようである.

（4）ガラス繊維一セメントペースト界面領域の微小 硬度分布は，混和材を混入しても大きな変化は認められ ない。しかし, 養生温度は界面領域の微小硬度分布に大 きな影響を及ぼし， $38^{\circ} \mathrm{C}$ の促進養生下では早期に不均 質な組織が形成される.

（5）ガラス繊維近傍におけるCaに富んだ領域の存 在とガラス繊維補強モルタルの脆性化との関係は明確で はない. ガラス繊維-セメントペースト界面領域の微小 硬度分布と $\mathrm{Ca} / \mathrm{Si}$ カウント比分布との関係も明らかで ない.

（6）ガラス繊維-セメントペースト界面領域の組織 の変化は長期にわたって継続し，界面隣接部分のペース トの剛性の増大および界面から $20 \mu \mathrm{m}$ から $100 \mu \mathrm{m}$ 付近 における不均質な構造の形成が特徴的である.

（7）界面から約 $20 \mu \mathrm{m}$ から $100 \mu \mathrm{m}$ 付近までに形成 される不均質な構造はガラス繊維に向かって進行するひ びわれの発生，伝播を容易にすると考えられる，ガラス 繊維補強モルタルの脆性化の顕著なものほ亡゙，この界面 領域の不均質性が強く現われるので，ガラス繊維補強モ ルタルの脆性化はこの界面領域の不均質な組織の形成と 関係すると考えられる.

\section{参 考 文 献}

1）小林一輔：繊維補強コンクリート一特性と応用一，オー 厶社, pp. 211 219, 1981.

2) Okada, K. and Kobayashi, K. : Applications of glass fibers for concrete beams, Second Australian Conference on Engineering Materials, pp. 461 472, 1981.

3) True, G. : GRC, Production \& Uses, pp. 83 96, A Viewpoint Publication, 1986.

4）河野 清, ほか：ガラス繊維補強コンクリートに対する シリカフュームの利用，セメント技術年報， 39 , pp. 470 $\sim 473,1985$

5）日本コンクリート工学協会：繊維補強セメントコンク リート複合材料の技術の現状と将来, pp. 12２4，1986.

6）牛島 栄，ほか：ガラス繊維と超速硬セメントを用いた 吹付けモルタルの施工方法及び諸性状，コンクリート工 学年次論文報告集，第 9 巻，第 1 号, pp. 479 482, 1987.

7）真嶋光保：ガラス繊維補強コンクリートの材料特性之舗 装への適用に関する研究, 1984.

8）川村満紀・五十嵐心一：未発表資料

9) Litherland, K. L. and Proctor, B.A. : The effect of matrix formulation, fibre content, and fibre composition on the durability of glass fibre reinforced cement, Proc. Durability of Glass Fiber Reinforced Concrete Symposium, P. C. I., pp. 124 135, 1985.

10) Stucke, M.S. and Majumdar, A. J. : Microstructure of glass fiber-reinforced cement composites, Journal of 
Materials Science, 11, pp.1019 1030, 1976.

11) Cohen, E. B. and Diamond, S. : Validity of flexural strength reduction as an indication of alkali attack on glass fiber reinforced cement composites, Proc. RILEM Symp. Fibre Reinforced Cement and Concrete, pp. 315 -325, 1975.

12) Diamond, S. : The GFRC durability problem : nature, characteristics, and test methods, Proc. Durability of Glass Fiber Reinforced Concrete Symposium, PCI, pp. 199 209, 1985.

13) Mills, P.H. : Age-embrittlement of glass-reinforced concrete containing blastfurnace slag, Cement and Concrete Research, Vol.11, pp.421 428, 1981.

14) Singh, B., Majumdar, A. J. and Ali, M. A. : Properties of grc containing pfa, The Inter. J. Cement Composites and Lightweight Concrete, Vol.6, No.2, pp. 65 74, 1984.

15) Leonard, S. and Bentur, A. : Improvement of the durability of glass fiber reinforced cement using blended cement matrix, Cement and Concrete Research, Vol.14, pp. $717 \sim 728,1984$.

16) Bentur, A. and Diamond, S. : Direct incorporation of silica fume into glass fibre strands as a means for developing GFRC composites of improved durability, The Inter. J. Cement Composites and Lightweight concrete, Vol.9, No. 3, pp. 127 135, 1987.

17) Diamond, S. : The microstructures of cement in concrete, Proc. 8th International Congress on the Chemistry of Cement, Vol. 1, pp. 127 147, 1986.
18) Bentur, A. et al. : The microstructure of the steel fibercement interface, Journal of Materials, Science, 20, pp. 3610 3620, 1985.

19) Wei, S., Mandel, J. A. and Said, S. : Study of the interface strength in steel fiber-reinforced cementbased composites, ACI Journal, pp. 597 605, 1986.

20）川村満紀：アルカリ骨材反応の機構，アルカリ骨材反応 に関するシンポジウム, 日本材料学会, pp.3〜28, 1985.

21) Watt, W. and Perov, B. V. : Strong Fibers, NorthHolland, pp. $61 \sim 85,1985$.

22) Malhotra, V. M. et al. : Condensed Silica Fume, pp. 53 $\sim 82$, CRC Press, Inc., 1987.

23) Pinchin, D. J. and Tabor, D. : Interfacial phenomena in steel fibre reinforced cement II : Pull-out behavior of steel wires, Cement and Concrete Research, Vol.8, pp. 139 150, 1978.

24）後藤芳弘・今橋 聡：ガラス繊維強化セメントペースト における界面結合強度，セメント技術年報， $30 ，$ pp. 436 438, 昭和 51 年.

25）五十嵐心一・川村満紀：ガラス緎維とセメントペースト の付着に関する基礎的研究, 土木学会第 43 回年次学術講 演会講演概要集, 第 5 部, pp. 404 405, 1988.

26) Majumdar, A.J. et al. : The durability of glass fibre cement - the effect of fibre length and content, Journal of Materials Science, 15, pp. 1085 1096, 1980.

27) Marsh, H. N. and Clarke, L. L. : Glass fiber reinforced concrete, ACI publication SP-44, pp. 247 264, 1974.

(1989.2.1 • 受付) 